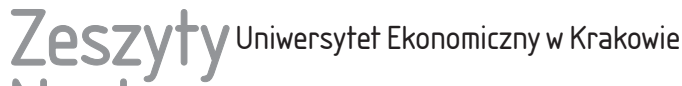 Naukowe
}

\section{Informacja o kapitale intelektualnym w sprawozdaniach z działalności i sprawozdaniach finansowych spółek branży lekowej}

\section{Streszczenie}

Cel: Celem artykułu jest zbadanie szczegółowości ujawniania informacji o kapitale intelektualnym w sprawozdawczości finansowej i niefinansowej za lata 2017 i 2018 spółek produkujących leki zarejestrowanych w Polsce, notowanych na Giełdzie Papierów Wartościowych w Warszawie.

Metodyka badań: Przygotowanie artykułu poprzedzone zostało przeglądem literatury przedmiotu dotyczącej badanego zagadnienia - artykułów naukowych, rozdziałów w monografiach, raportów branżowych oraz aktów prawnych. W badaniu wykorzystano metodę badania dokumentów - sprawozdań finansowych i niefinansowych analizowanych przedsiębiorstw.

Krzysztof Mataczyna, Szkoła Główna Handlowa w Warszawie, Kolegium Zarządzania i Finansów, al. Niepodległości 162, 02-554 Warszawa, e-mail: km56710@doktorant.sgh.waw.pl, ORCID: https://orcid.org/0000-0002-7479-9375.

Joanna Wielgórska-Leszczyńska, Szkoła Główna Handlowa w Warszawie, Kolegium Zarządzania i Finansów, al. Niepodległości 162, 02-554 Warszawa, e-mail: jwielg@sgh.waw.pl, ORCID: https:// orcid.org/0000-0002-3521-6325.

Artykuł udostępniany na licencji Creative Commons Uznanie autorstwa-Użycie niekomercyjne-Bez utworów zależnych 4.0 (CC BY-NC-ND 4.0); https://creativecommons.org/licenses/ by-nc-nd/4.0/ 
Wyniki badań: Wyniki przeprowadzonych badań wskazują, że analizowane przedsiębiorstwa nie sporządzają osobnych sprawozdań dotyczących kapitału intelektualnego, ale informacje o tym kapitale zawierają w sprawozdaniach z działalności i sprawozdaniach finansowych, a szczegółowość tych informacji jest zróżnicowana.

Wnioski: Zróżnicowanie szczegółowości ujawnianych informacji o kapitale intelektualnym potwierdza konieczność działań zmierzających do standaryzacji informacji o kapitale intelektualnym ujawnianych w sprawozdaniach z działalności i sprawozdaniach finansowych.

Wkład w rozwój dyscypliny: Przeprowadzone badania mogą stanowić wstęp do szerszych badań nad ujawnianiem informacji o kapitale intelektualnym w przedsiębiorstwach branży lekowej, a także nad znaczeniem kapitału intelektualnego dla kondycji finansowej przedsiębiorstw.

Słowa kluczowe: kapitał intelektualny, sprawozdawczość niefinansowa, sprawozdawczość finansowa, branża lekowa.

Klasyfikacja JEL: M41, J24, O34.

\section{Wprowadzenie}

Upowszechnienie modelu gospodarki opartej na wiedzy rozumianej, zgodnie z definicją Organizacji Współpracy Gospodarczej i Rozwoju (OECD), jako gospodarka bezpośrednio bazująca na produkcji, dystrybucji oraz stosowaniu wiedzy i informacji (Piech 2004), ale także dążenie do zrównoważonego rozwoju, rosnące znaczenie ładu korporacyjnego oraz zwiększenie dostępności informacji o przedsiębiorstwie dla zainteresowanych stron (Skoczylas i Dziadul 2018, s. 118) uwidoczniło zarówno zarządzającym przedsiębiorstwami, jak i akcjonariuszom oraz organom kontrolnym potrzebę raportowania danych dotyczących pozafinansowych nośników mających swój udział w generowaniu łańcucha wartości tych przedsiębiorstw. Przykładem takiego nośnika jest kapitał intelektualny, którego znaczenie w gospodarce opartej na wiedzy stale wzrasta.

Celem artykułu jest zbadanie szczegółowości ujawnianych informacji o kapitale intelektualnym w sprawozdawczości finansowej i niefinansowej zarejestrowanych w Polsce spółek produkujących leki, notowanych na Giełdzie Papierów Wartościowych w Warszawie. Wybór branży farmaceutycznej jest zdaniem autorów podkreśleniem wagi kapitału intelektualnego w funkcjonowaniu tej branży, co przejawia się we współpracy jednostek działających w branży farmaceutycznej z jednostkami badawczo-rozwojowymi - krajowymi i zagranicznymi, permanentnym procesem udoskonalania wytwarzanych produktów w oparciu o posiadane patenty, receptury, know-how czy własne procedury, wydatkami tych jednostek na doskonalenie wiedzy i umiejętności zaangażowanego zasobu ludzkiego czy działaniami utrwalającymi relacje tych jednostek z interesariuszami. 
Przygotowanie niniejszego artykułu poprzedziło dokonanie przeglądu literatury przedmiotu dotyczącej badanego zagadnienia - artykułów naukowych, rozdziałów w monografiach, raportów branżowych oraz aktów prawnych. W badaniu wykorzystano metodę badania dokumentów - sprawozdań finansowych i niefinansowych analizowanych spółek.

\section{Kapitał intelektualny a sprawozdawczość finansowa i niefinansowa}

Tradycyjna rachunkowość skupiona jest na ewidencjonowaniu i przetwarzaniu danych finansowych mierzonych w jednostkach pieniężnych i prezentowaniu ich w sprawozdaniu finansowym, na które składają się zgodnie z art. 10 MSR 1: sprawozdanie z sytuacji finansowej na koniec okresu, sprawozdanie z zysków lub strat i innych całkowitych dochodów za dany okres, sprawozdanie ze zmian w kapitale własnym za dany okres, sprawozdanie z przepływów pieniężnych za dany okres, informacje dodatkowe zawierające podsumowanie istotnych zasad (polityki) rachunkowości oraz inne informacje objaśniające. Podobna regulacja funkcjonuje w polskim prawie bilansowym, czyli w ustawie o rachunkowości. Żaden z wyżej wymienionych dokumentów nie jest skoncentrowany na raportowaniu zasobów ludzkich, organizacyjnych czy relacji biznesowych między przedsiębiorstwami lub między przedsiębiorstwem a innymi interesariuszami.

Spółki, oprócz sprawozdania finansowego, sporządzają również sprawozdania z działalności, raporty dotyczące społecznej odpowiedzialności biznesu czy sprawozdania zintegrowane. Raportowanie informacji niefinansowych w krajach członkowskich Unii Europejskiej zostało częściowo uregulowane przez dyrektywę Parlamentu Europejskiego i Rady 2014/95/UE oraz wydane do niej wytyczne dotyczące sprawozdawczości w zakresie informacji niefinansowych. Powyższe regulacje sygnalizują, że ustawodawca unijny dostrzega potrzebę standaryzacji sposobu raportowania informacji niefinansowych w celu zapewnienia dostępu do niej zainteresowanym podmiotom.

Sprawozdawczość niefinansowa stanowi podstawę do ujawnienia informacji dotyczących kapitału intelektualnego przedsiębiorstwa. Definicja kapitału intelektualnego nie jest w literaturze przedmiotu jednoznaczna. Często wskazuje się, że kapitał intelektualny stanowi różnicę pomiędzy wartością rynkową a wartością księgową (Edvinsson i Malone 2001, s. 39). L. Niemczyk (2015, s. 27) zauważa jednak, że formuła ta jest daleko niewystarczająca, na co zdaniem autora wpływ ma fakt, że nie wszystkie elementy składające się na kapitał intelektualny znajdują odzwierciedlenie w wartości rynkowej jednostki. Autor przychyla się do poglądu, że najważniejszą cechą kapitału intelektualnego jest jego niepieniężność, 
dotyczy on bowiem cech jakościowych przedsiębiorstwa (Skrzypek 2017, s. 95). W związku z tym ujawnianie danych niefinansowych ma kluczowe znaczenie z punktu widzenia całościowej oceny kondycji przedsiębiorstwa.

Kapitał intelektualny opiera się w dużej mierze na wiedzy. Jak wskazuje J. Dumay (2016, s. 169), główną składową kapitału intelektualnego jest suma wiedzy, którą posiada każdy zatrudniony w organizacji, a także jego doświadczenie, inteligencja oraz posiadane informacje, które mogą zostać użyte do kreacji wartości. A. Ujwary-Gil słusznie jednak zauważa, że wiedza ulega dewaluacji $\mathrm{z}$ biegiem czasu oraz możliwe jest także jej poszerzanie, wobec tego wspomniana suma wiedzy odnosić się powinna tylko do wiedzy faktycznie „uzewnętrznionej” (Ujwary-Gil 2010, s. 91), czyli wykorzystywanej w toku działalności przedsiębiorstwa. Podkreśla się również, że kapitał intelektualny stanowi jedną z przyczyn uzyskiwania bądź utrzymywania przewagi konkurencyjnej (Skrzypek 2017, s. 96). Posiadana wiedza przekłada się na możliwość tworzenia optymalnych procedur i regulacji wewnątrz przedsiębiorstwa, prowadzenia prac badawczo-rozwojowych, a więc tworzenia know-how, receptur, a w dalszej kolejności uzyskiwania patentów czy licencji. Ma ona również wpływ na tworzenie relacji przedsiębiorstwa z klientami, innymi przedsiębiorstwami, otoczeniem instytucjonalnym, społecznościami lokalnymi czy na stopień oddziaływania na środowisko naturalne. W tym ujęciu właściwa wydaje się zatem dominująca w literaturze przedmiotu od początku XXI w. (Mouritsen 2009, s. 154) definicja kapitału intelektualnego jako sumy trzech składowych: kapitału ludzkiego, kapitału strukturalnego (nazywanego również organizacyjnym) oraz kapitału relacyjnego. Przytoczona kategoryzacja jest wykorzystywana w badaniach empirycznych dotyczących kapitału intelektualnego w przedsiębiorstwach na całym świecie (Inkinen i in. 2017, s. 1161), dlatego zdecydowano się przyjąć tę definicję w niniejszym artykule.

Kapitał ludzki stanowi wiedza pracowników i menedżerów zatrudnionych w przedsiębiorstwie, a także ich doświadczenie, zdobyte wykształcenie i umiejętności. Należy jednak podkreślić, że kapitał ludzki nie stanowi własności przedsiębiorstwa, a jest własnością zatrudnionych. Odejście pracownika bądź menedżera z przedsiębiorstwa skutkuje więc utratą kapitału ludzkiego udostępnianego przez nich tej jednostce (Niemczyk 2015, s. 28). Istotnymi elementami kapitału ludzkiego są również motywacja pracowników oraz zdobywanie przez nich nowych i poszerzanie posiadanych kwalifikacji. Kapitał ludzki przedsiębiorstwa może wywierać na nie wpływ zarówno pozytywny, jak i negatywny - pozytywny wówczas, gdy powyższe atrybuty wykorzystywane są w celu zbieżnym $\mathrm{z}$ celem funkcjonowania przedsiębiorstwa, a negatywny, gdy działania zatrudnionych stoją w sprzeczności z celami przedsiębiorstwa, czyli np. w przypadku wykorzystywania przez pracowników wiedzy i umiejętności do działania na szkodę jednostki lub na korzyść konkurencji. Sporą trudnością jest kwestia mierzalności kapitału ludzkiego. 
W raportach niefinansowych prezentowane są wskaźniki dotyczące struktury wiekowej, płci, zatrudnienia, wykształcenia, absencji czy efektywności pracowników. Są to jednak wielkości odnoszące się do pewnej zbiorowości i pomijają wszelką indywidualność i kreatywność zatrudnionych (Mouritsen 2009, s. 159). Rola tych cech jest coraz ważniejsza w kontekście upowszechniania się gospodarki opartej na wiedzy i dążenia przedsiębiorstw do bycia bardziej innowacyjnymi.

Kolejną składową kapitału intelektualnego jest kapitał strukturalny (nazywany również organizacyjnym lub wewnętrznym), który odnosi się do organizacyjnych zasobów intelektualnych przedsiębiorstwa. Podkreślenia wymaga, że kapitał strukturalny stanowi własność przedsiębiorstwa (Kwiecińska 2018, s. 319) w przeciwieństwie do kapitału ludzkiego. W literaturze przedmiotu najczęściej wskazuje się następujące elementy kapitału strukturalnego: posiadane przez przedsiębiorstwo patenty, licencje, prawa autorskie, wiedza organizacyjna, receptury, funkcjonujące w przedsiębiorstwie procedury, systemy, regulacje wewnętrzne, kultura organizacyjna (Duff 2018, s. 771). Kapitał strukturalny jest więc niejako wbudowany w przedsiębiorstwo, zapewnia stabilne działanie przedsiębiorstwa wobec rotacji pracowników czy relacji z klientami, kontrahentami, dostawcami oraz innymi interesariuszami.

Ostatnim elementem dopełniającym kapitał intelektualny przedsiębiorstwa jest kapitał relacyjny (nazywany również zewnętrznym). Jego istotą są relacje przedsiębiorstwa z różnymi grupami interesariuszy: dostawcami, klientami, społecznościami lokalnymi, instytucjami państwa i samorządu oraz oddziaływanie na środowisko naturalne. Przykładami takich relacji może być marka, satysfakcja klientów, reputacja przedsiębiorstwa czy kontakty z dostawcami (Duff 2018, s. 771).

Z przytoczonych definicji wynika, że informacje dotyczące kapitału intelektualnego mają przede wszystkim charakter niefinansowy, co oznacza, że są one ujawniane w ramach sprawozdawczości niefinansowej, która jest regulowana przez Ustawę z dnia 29 września 1994 r. o rachunkowości (dalej: uor). Należy więc zwrócić uwagę na poszczególne wymagania stawiane przez ustawodawcę w kontekście informacji o kapitale intelektualnym. Głównym dokumentem w tej materii jest sprawozdanie z działalności jednostki sporządzane przez jej kierownika, o którym stanowi art. 49 uor. Zgodnie z art. 49 ust. 2 uor sprawozdanie to „powinno obejmować istotne informacje o stanie majątkowym i sytuacji finansowej, w tym ocenę uzyskiwanych efektów oraz wskazanie czynników ryzyka i opis zagrożeń", m.in. informacje o przewidywanym rozwoju jednostki, ważniejszych osiągnięciach w dziedzinie badań i rozwoju. W art. 49 ust. 2a uor, odnoszącym się do emitentów, których papiery wartościowe zostały dopuszczone do obrotu na jednym z rynków regulowanych EOG, wskazuje się na obowiązek sporządzenia oświadczenia o stosowaniu ładu korporacyjnego, które stanowić ma wyodrębnioną część sprawozdania z działalności. W art. 49 ust. 3 uor nakłada 
się również, pod warunkiem że ,jest to istotne dla oceny rozwoju, wyników i sytuacji jednostki", ujawnienie informacji dotyczących kluczowych finansowych wskaźników efektywności związanych z działalnością jednostki oraz kluczowych niefinansowych wskaźników efektywności związanych z działalnością jednostki oraz informacji dotyczących zagadnień pracowniczych i środowiska naturalnego.

W kontekście ujawniania informacji niefinansowych należy także zwrócić uwagę na art. 49b uor, będący implementacją Dyrektywy Parlamentu Europejskiego i Rady 2014/95/UE z dnia 22 października 2014 r. zmieniającej dyrektywę 2013/34/UE w odniesieniu do ujawniania informacji niefinansowych i informacji dotyczących różnorodności przez niektóre duże jednostki oraz grupy. Przepis ten dotyczy jednostek, które przekraczają łącznie następujące wielkości: średnioroczne zatrudnienie w przeliczeniu na etaty wynosi 500 osób oraz suma aktywów bilansu na koniec roku obrotowego wynosi 85000000 zł lub przychody netto ze sprzedaży towarów i produktów za rok obrotowy wynoszą 170000000 zł. W maju 2020 r. zakończyły się konsultacje publiczne Komisji Europejskiej w związku z rewizją dyrektywy w sprawie ujawniania informacji niefinansowej. Komisja Europejska wskazuje na rosnące zapotrzebowanie inwestorów na informację niefinansową, zwłaszcza w kontekście ryzyka finansowego związanego ze zrównoważonym rozwojem oraz zwiększającego się udziału produktów finansowych, których celem jest „aktywne rozwiązywanie problemów środowiskowych i społecznych” (Rewizja dyrektywy... 2020).

Art. 49b uor wprowadza dla jednostek spełniających przytoczone wyżej kryteria obowiązek sporządzenia oświadczenia na temat informacji niefinansowych, obejmującego co najmniej, zgodnie z art. 49b ust. 2 uor, ogólny opis modelu biznesowego jednostki, kluczowe niefinansowe wskaźniki efektywności związane $\mathrm{z}$ działalnością jednostki, opis polityk stosowanych przez jednostkę w odniesieniu do zagadnień społecznych, pracowniczych, środowiska naturalnego, poszanowania praw człowieka oraz przeciwdziałania korupcji wraz z opisem rezultatów stosowania tych polityk. Ponadto w oświadczeniu powinny znaleźć się informacje dotyczące procedur należytej staranności (w przypadku ich stosowania w odniesieniu do ww. polityk) oraz opis istotnych ryzyk związanych z działalnością jednostki mogących wywierać niekorzystny wpływ na zagadnienia związane z ww. politykami. Kolejną kwestią, której odzwierciedleniem są przepisy art. 49b ust. 4 uor, jest powiązanie wartości wykazywanych w rocznym sprawozdaniu finansowym z danymi ujawnianymi w oświadczeniu na temat informacji niefinansowych. W tym kontekście, jeżeli powiązania te występują, należy zawrzeć w oświadczeniu stosowne odniesienia oraz dodatkowe wyjaśnienia dotyczące wspomnianych kwot (np. wartości niematerialnych, danych o przychodach i kosztach, wyników finansowych czy liczby zatrudnionych) w sprawozdaniu finansowym. 
Poza wymogami ustawowymi istnieje wiele koncepcji związanych z ujawnianiem kapitału intelektualnego w osobnych sprawozdaniach. Jedną z takich koncepcji jest InCaS (intellectual capital statement - sprawozdanie z kapitału intelektualnego), w której wzięto pod uwagę trzy składowe kapitału intelektualnego (kapitał ludzki, kapitał relacyjny i kapitał organizacyjny), wskazując na wzajemne ścisłe powiązanie tych kapitałów (Szczepankiewicz 2013, s. 138). InCaS, jako narzędzie służące do pomiaru i raportowania kapitału intelektualnego małych i średnich przedsiębiorstw, miało swoje początki w 2006 r., a jego powstanie zostało zainicjowane przez Komisję Europejską (Szczepankiewicz 2012, s. 79). Narzędzie InCaS opiera się na wyznaczeniu wskaźników odnoszących się do poszczególnych składowych kapitału intelektualnego i następnie wyznaczeniu wartości, jakości, średniej wartości czy potencjału wzrostu czynników wpływających na poszczególne składowe kapitału intelektualnego. Dla kapitału ludzkiego będą to m.in. motywacja, zdolności przywódcze czy znajomość języków obcych (Szczepankiewicz 2012, s. 85). InCaS zostało pilotażowo wdrożone w kilkudziesięciu małych i średnich przedsiębiorstwach w Europie (Szczepankiewicz 2012, s. 79), jednak sporządzanie odrębnego sprawozdania dotyczącego kapitału intelektualnego czy wykorzystanie metod pomiaru InCaS nie jest obowiązkowe.

Obecnie, wobec zwiększającego się zapotrzebowania interesariuszy na dostęp do informacji niefinansowych zaprezentowanych $\mathrm{w}$ powiązaniu $\mathrm{z}$ informacjami finansowymi, w coraz większym stopniu uznanie zyskuje także koncepcja raportowania zintegrowanego (integrated reporting - IR). Ma to związek z raportowaniem przez jednostki wielu informacji o ich działalności w różnych sprawozdaniach równolegle, co powoduje, że nierzadko obszary tematyczne w nich zaprezentowane pokrywają się, natomiast trudności nastręcza odnalezienie powiązań przedstawionych wyników finansowych i niefinansowych (Michalczuk i Mikulska 2014, s. 199).

Odpowiedzią na potrzebę zestawiania informacji finansowych i niefinansowych oraz wskazywania powiązań między nimi jest sprawozdanie zintegrowane, którego zarys i pożądaną zawartość zaprezentowano w The International Integrated Reporting Framework (2013). We wstępie do tego dokumentu zawarto główne postulowane cele, do których powinno się dążyć w sprawozdaniu zintegrowanym. Spośród tych celów, w kontekście przedmiotu badań w niniejszym artykule, istotne jest wzmocnienie odpowiedzialności i nadzoru nad szerokim spektrum kapitałów (finansowym, produkcyjnym, intelektualnym, ludzkim, społecznym i relacyjnym oraz naturalnym) i wskazywanie współzależności pomiędzy nimi (The International... 2013, s. 2).

The International Integrated Reporting Framework nie stanowi obecnie obowiązującego standardu, a jedynie wskazówkę dla jednostek sporządzających sprawozdanie zintegrowane, przy czym należy zwrócić uwagę, że jego sporzą- 
dzanie w krajach Unii Europejskiej nie jest obowiązkowe. Jedynym krajem, w którym istnieje obowiązek sporządzania sprawozdania zintegrowanego dla spółek notowanych na giełdzie Johannesburg Stock Exchange jest Republika Południowej Afryki (Chojnacka i Bering 2018, s. 64). Obowiązek ten ma jednak charakter prawa miękkiego, co oznacza, że jednostka, która takiego sprawozdania nie sporządzi, jest zobowiązana do wyjaśnienia, dlaczego od tego obowiązku odstąpiła (Michalczuk i Mikulska 2014, s. 202).

W związku z powyższym, wobec braku obowiązku sporządzania sprawozdania zintegrowanego przez spółki notowane na Giełdzie Papierów Wartościowych w Warszawie, analizie w kontekście sposobu ujawniania informacji na temat kapitału intelektualnego zostały poddane sprawozdania finansowe oraz sprawozdania z działalności, w których - zgodnie z przytoczonymi przepisami uor - znalazły się pożądane informacje.

\section{Metodyka badania wybranych spółek branży lekowej}

Na potrzeby niniejszego artykułu analizie zostały poddane sprawozdania finansowe i sprawozdania z działalności za lata 2017 i 2018 spółek notowanych na Giełdzie Papierów Wartościowych w Warszawie z sektora oznaczonego na stronie ww. instytucji jako „produkcja leków”. Spośród spółek należących do tego sektora wzięte pod uwagę zostały te, które zarejestrowane są na terenie Rzeczypospolitej Polskiej. Dzięki temu możliwe jest porównanie zawartości sprawozdań sporządzanych w danym porządku prawnym w kontekście raportowania kapitału intelektualnego. Analiza dotyczy zatem sprawozdań następujących spółek: Biomed-Lublin Wytwórnia Surowic i Szczepionek SA, Bioton SA, Celon Pharma SA, PZ Cormay SA, Mabion SA, Master Pharm SA, Pharmena SA.

Badanie objęło sprawozdania za lata 2017 i 2018, co umożliwia z jednej strony dokonanie porównania ujawnianych przez spółki informacji dotyczących kapitału intelektualnego w obu okresach, a z drugiej odwołanie do najbardziej aktualnych sprawozdań, sporządzanych zgodnie nie tylko z obecnie obowiązującymi przepisami i standardami, ale także trendami współczesnej sprawozdawczości, jak np. raportowanie z większą szczegółowością kwestii związanych z ochroną środowiska naturalnego czy współpracą ze społecznościami lokalnymi i instytutami badawczymi.

\section{Wyniki badań}

Spośród badanych jednostek pięć z nich (Biomed-Lublin Wytwórnia Surowic i Szczepionek SA, Bioton SA, PZ Cormay SA, Mabion SA i Master Pharm SA) 
sporządzały w badanych okresach sprawozdania finansowe zgodnie z międzynarodowymi standardami sprawozdawczości finansowej (MSSF), a dwie pozostałe (Celon Pharma SA i Pharmena SA) zgodnie z ustawą o rachunkowości. W kontekście przywołanego art. 49b uor, dotyczącego rozszerzonego obowiązku sprawozdawczego dla danych niefinansowych, z punktu widzenia jednostek będących przedmiotem badania przepis ten będzie miał zastosowanie jedynie w odniesieniu do spółki Bioton. Pozostałe spółki nie wykazują wielkości wymienionych w tym przepisie, co zostało uwidocznione w tabeli 1 . Z przeprowadzonej analizy wynika, że spółka Bioton zawarła w swoim sprawozdaniu z działalności oświadczenie na temat informacji niefinansowych, czym wypełniła obowiązek wskazany w art. $49 \mathrm{~b}$ uor.

Tabela 1. Suma aktywów bilansu i przychody ze sprzedaży towarów i produktów w latach 2017 i 2018 (dane dotyczące sumy aktywów bilansu i przychodów ze sprzedaży towarów i produktów zostały podane w tys. zł)

\begin{tabular}{|l|c|c|c|c|c|c|}
\hline \multirow{2}{*}{ Spółka } & \multicolumn{2}{|c|}{$\begin{array}{c}\text { Suma aktywów } \\
\text { bilansu } \\
\text { na koniec roku }\end{array}$} & \multicolumn{2}{c|}{$\begin{array}{c}\text { Przychody ze } \\
\text { sprzedaży towarów } \\
\text { i produktów za rok }\end{array}$} & \multicolumn{2}{c|}{$\begin{array}{c}\text { Średnioroczne } \\
\text { zatrudnienie } \\
\text { w przeliczeniu } \\
\text { na etaty w roku }\end{array}$} \\
\cline { 2 - 8 } & 2017 & 2018 & 2017 & 2018 & 2017 & 2018 \\
\hline $\begin{array}{l}\text { Biomed-Lublin Wytwórnia } \\
\text { Surowic i Szczepionek SA }\end{array}$ & 121027 & 86255 & 31404 & 32293 & 211 & 221 \\
\hline Bioton SA & 1240400 & 1055204 & 241808 & 197043 & 508 & 466 \\
\hline Celon Pharma SA & 525050 & 563668 & 107120 & 125145 & 271 & 297 \\
\hline PZ Cormay SA & 147724 & 125565 & 42027 & 41016 & 181 & 181 \\
\hline Mabion SA & 82445 & 144717 & 0 & 0 & 137 & 137 \\
\hline Master Pharm SA & 85515 & 86358 & 52087 & 61936 &. & . \\
\hline Pharmena SA & 46634 & 44917 & 13458 & 13993 & 20 & 19 \\
\hline
\end{tabular}

Źródło: opracowanie własne na podstawie sprawozdań finansowych i sprawozdań z działalności badanych spółek.

Informacje dotyczące kapitału intelektualnego ujawniane były w przeważającym stopniu w sprawozdaniach z działalności. Wyjątek stanowiły dane dotyczące kosztów wynagrodzeń, zmian wartości w pozycji „,wartości niematerialne” lub „wartości niematerialne i prawne”, trwałej utraty wartości tychże aktywów oraz dane o kosztach prac badawczo-rozwojowych, które ujawniane były w sprawozdaniach finansowych.

Mając na uwadze przedmiot badania, jakim jest szczegółowość ujawnianych informacji dotyczących kapitału intelektualnego w sprawozdawczości finansowej i niefinansowej jednostek, oraz wymogi ustawowe nakładane na jednostki, można 
wyodrębnić główne z punktu widzenia definicji kapitału intelektualnego informacje ujawniane w sprawozdaniach finansowych i sprawozdaniach z działalności. $\mathrm{W}$ tym celu, zgodnie z przyjętą przez autorów definicją kapitału intelektualnego, wyniki badania zostaną zaprezentowane w trzech blokach, odpowiadających składowym kapitału intelektualnego, a więc kapitałowi ludzkiemu, kapitałowi strukturalnemu oraz kapitałowi relacyjnemu.

Szczegółowość raportowania w zakresie kapitału ludzkiego jest zróżnicowana. W sprawozdaniach wszystkich spółek za lata 2017 i 2018 znalazły się informacje dotyczące kapitału ludzkiego, które obejmowały dane na temat kosztów wynagrodzeń ogółu zatrudnionych oraz regulacje wewnętrzne dotyczące wynagradzania zarządów i rad nadzorczych, a także informacje o przeciętnym zatrudnieniu. Pozostałe kwestie związane z kapitałem ludzkim raportowane były przez spółki z różną szczegółowością, co zostało przedstawione w tabeli 2.

Tabela 2. Informacje dotyczące kapitału ludzkiego ujawniane w sprawozdaniach finansowych i sprawozdaniach z działalności przez badane spółki w latach 2017 i 2018

\begin{tabular}{|l|l|}
\hline \multicolumn{1}{|c|}{ Spółka } & \multicolumn{1}{c|}{ Ujawniane informacje } \\
\hline Wszystkie spółki & $\begin{array}{l}\text { koszty wynagrodzeń ogółu zatrudnionych } \\
\text { - przeciętne zatrudnienie } \\
\text { - regulacje wewnętrzne dotyczące wynagradzania zarządów i rad } \\
\text { nadzorczych }\end{array}$ \\
\hline Biomed-Lublin & - ryzyko (związane z pozyskaniem lub utratą wykwalifikowanej kadry \\
Wytwórnia Surowic & w związku z prowadzoną restrukturyzacją oraz związane z ujawnie- \\
i Szczepionek SA & niem tajemnic handlowych przez byłych lub obecnych pracowników) \\
- & eliminacja ziszczenia się ryzyka związanego z opóźnieniami w reje- \\
& stracji leków dzięki wysoko wykwalifikowanej i doświadczonej \\
& kadrze \\
- rotacja pracowników \\
Bioton SA
\end{tabular}


cd. tabeli 2

\begin{tabular}{|c|c|}
\hline Spółka & Ujawniane informacje \\
\hline PZ Cormay SA & $\begin{array}{l}\text { - dostęp do wyspecjalizowanej kadry, lokalizacja znacznej wartości } \\
\text { produkcji i centrum usług wspólnych w Polsce ze względu na niskie } \\
\text { koszty pracy } \\
\text { - pozapłacowe świadczenia pracownicze (obowiązkowe - odzież } \\
\text { ochronna, posiłki, napoje dla osób pracujących w określonych warun- } \\
\text { kach i dodatkowe - szkolenia, możliwośc korzystania ze sprzętu służ- } \\
\text { bowego do celów prywatnych, dostęp do prywatnej opieki medycznej) } \\
\text { - struktura zatrudnienia (podział na stanowiska robotnicze i nierobot- } \\
\text { nicze) i uzasadnienie zmian w strukturze }\end{array}$ \\
\hline Mabion SA & $\begin{array}{l}\text { - dane dotyczące personelu badawczego, którego wiedza i doświadcze- } \\
\text { nie są kluczowe w związku z prowadzonymi przez spółkę badaniami } \\
\text { - finansowanie udziału pracowników w konferencjach i szkoleniach } \\
\text { zagranicznych } \\
\text { - ryzyko utraty kluczowych pracowników } \\
\text { - informacja o polityce wynagrodzeń (nie występuje) i zobowiąza- } \\
\text { niach z tytułu emerytur i świadczeń o podobnym charakterze } \\
\text { (nie występują) } \\
\text { - informacja na temat wsparcia rozwoju zawodowego i osobistego } \\
\text { pracowników } \\
\text { - informacja o systemie szkoleń i badaniu motywacji pracowników } \\
\text { oraz procedurze awansów } \\
\text { - informacja o współpracy z biurami karier uczelni wyższych }\end{array}$ \\
\hline Master Pharm SA & $\begin{array}{l}\text { - informacja o możliwości odbycia szkoleń przez pracowników, } \\
\text { dofinansowania studiów } \\
\text { - informacja o funkcjonujących procedurach: procedury awansu, } \\
\text { wdrażanie programów premiowych, wdrażanie programów lojalno- } \\
\text { ściowych }\end{array}$ \\
\hline Pharmena SA & - informacja o ryzyku związanym z kadrą menedżerską \\
\hline
\end{tabular}

Źródło: opracowanie własne na podstawie sprawozdań finansowych i sprawozdań z działalności badanych spółek.

Większość spółek podkreślała w swoich sprawozdaniach wagę wysoko wykwalifikowanych zasobów ludzkich, wskazując je w kontekście możliwego do ziszczenia ryzyka, czynników tworzących wartość i kulturę organizacyjną przedsiębiorstwa czy kluczową wiedzę i doświadczenie tych zasobów w toku prowadzonych badań. Bioton, Celon Pharma, PZ Cormay, Mabion i Master Pharm ujawniły informacje dotyczące możliwości korzystania przez pracowników tych spółek ze szkoleń czy dofinansowania dalszej edukacji. Bioton i Celon Pharma zasygnalizowały, że przeważającą formą zatrudnienia pracowników jest w ich przypadku umowa o pracę. Bioton i Cormay wskazały w sprawozdaniach, że pracownicy tych spółek mogą skorzystać z benefitów pozapłacowych. 
Ponadto, w badanych dokumentach zawarto stosunkowo niewiele informacji na temat obowiązujących w spółkach procedur związanych z kapitałem ludzkim. Na tym tle wyróżniają się spółki: Bioton (w zakresie informacji o obowiązujących procedurach dotyczących bhp i monitorowania zagrożeń oraz braku polityki różnorodności), Mabion (w zakresie informacji o braku polityki wynagrodzeń, obowiązującej procedurze awansów) oraz Master Pharm (w zakresie informacji o obowiązującej procedurze awansu). Tylko jedna spółka, Mabion, zawarła w sprawozdaniu z działalności informację o tym, że współpracuje z biurami karier polskich uczelni oraz prowadzi badanie motywacji pracowników.

Analiza sprawozdań finansowych i sprawozdań z działalności za lata 2017 i 2018 pozwala stwierdzić, że żadna ze spółek nie zmieniła w sposób istotny zakresu i szczegółowości ujawnianych przez siebie informacji związanych z kapitałem ludzkim, natomiast istnieją zasadnicze różnice między badanymi spółkami odnośnie do zakresu i szczegółowości ujawnianych informacji. Pozytywnie, zdaniem autorów, należy ocenić umieszczone w większości sprawozdań wskazanie o kluczowej wartości zasobów ludzkich dla prowadzonej przez badane spółki działalności. Warto jednak w tym kontekście zwrócić uwagę, że spółki w przeważającej większości nie posiadają lub nie informują o posiadaniu sformalizowanych procedur związanych z awansami, motywacją, polityką wynagrodzeń czy polityką różnorodności.

Szczegółowość prezentowanych w sprawozdaniach z działalności i sprawozdaniach finansowych informacji na temat kapitału strukturalnego nie uległa w badanych spółkach zmianom. Wyjątek stanowiły pojedyncze zdarzenia, które były specyficzne dla danego okresu sprawozdawczego, jak np. informacja o podpisanej umowie licencyjnej oraz oczekiwanych lub osiąganych przychodach z nią związanych.

Badane spółki ujawniały informacje dotyczące kapitału strukturalnego z podobną szczegółowością. Różnice w zakresie ujawnianych informacji wiązały się przede wszystkim z zakresem prowadzonej działalności. Sprawozdania z działalności wszystkich spółek zawierały informacje dotyczące posiadanych przez spółkę patentów, licencji, stosowania zasad ładu korporacyjnego i odstępstw od ich stosowania, procesów badawczo-rozwojowych i ich statusie. Pozostałe informacje raportowane przez spółki zostały przedstawione w tabeli 3.

Biomed-Lublin, PZ Cormay, Mabion i Master Pharm ujawniły informacje dotyczące uzyskanych certyfikatów zewnętrznych dotyczących zarządzania jakością, zgodności procesów badawczych i produkcyjnych z dobrymi praktykami czy spełniania norm zarządzania bezpieczeństwem żywności, co jest istotne dla interesariuszy, zwłaszcza w branży przedsiębiorstw produkujących leki. 
Tabela 3. Informacje dotyczące kapitału strukturalnego ujawniane w sprawozdaniach finansowych i sprawozdaniach z działalności przez badane spółki w latach 2017 i 2018

\begin{tabular}{|c|c|}
\hline Spółka & Ujawniane informacje \\
\hline Wszystkie spółki & $\begin{array}{l}\text { - kwestie związane z ochroną własności intelektualnej (informacja o posia- } \\
\text { danych patentach, licencjach, zarejestrowanych znakach towarowych) } \\
\text { - informacja o toczących się pracach badawczo-rozwojowych i ich statusie } \\
\text { - informacja o stosowaniu zasad ładu korporacyjnego i odstępstwach } \\
\text { od nich }\end{array}$ \\
\hline $\begin{array}{l}\text { Biomed-Lublin } \\
\text { Wytwórnia Surowic } \\
\text { i Szczepionek SA }\end{array}$ & $\begin{array}{l}\text { - informacja o posiadanym zezwoleniu GIF na produkcję leków } \\
\text { i wyrobów medycznych } \\
\text { - informacja o sprzedaży marki i przestawieniu na produkcję usługową } \\
\text { na rzecz nabywcy tej marki } \\
\text { - wytwarzane produkty i ich cechy wyróżniające na tle rynku polskiego } \\
\text { i europejskiego } \\
\text { - informacja o aktualizacji strategii na kolejne lata z zarysem założeń } \\
\text { strategii } \\
\text { - uzyskane certyfikaty i wyniki audytów międzynarodowych }\end{array}$ \\
\hline Bioton SA & $\begin{array}{l}\text { - informacja o funkcjonujących w spółce procedurach i rodzajach polityki } \\
\text { (procedury dotyczące kontroli jakości, polityka bezpieczeństwa informa- } \\
\text { cji, przeciwdziałania korupcji, poszanowania praw człowieka, środowi- } \\
\text { skowa, bezpieczeństwa i zgodności, kodeks etyki) } \\
\text { - informacja o audytach wewnętrznych dotyczących jakości produktów } \\
\text { i procesu produkcji } \\
\text { - informacja o wartości nakładów na badania i rozwój } \\
\text { - opis systemu kontroli wewnętrznej, informacja o prowadzonych } \\
\text { audytach i wstępnej kontroli dostawców }\end{array}$ \\
\hline Celon Pharma SA & $\begin{array}{l}\text { - informacja o oczekiwanych (2017) i uzyskanych (2018) przychodach } \\
\text { z licencji do praw z tytułu podpisanych umów, o odpłatnym udzieleniu } \\
\text { licencji, o zawartych umowach dotyczących rozwoju i wytwarzania leków } \\
\text { - informacja o założeniach strategii rozwoju i realizacji strategii } \\
\text { - zagadnienia dotyczące ochrony środowiska }\end{array}$ \\
\hline PZ Cormay SA & $\begin{array}{l}\text { - informacja o posiadanych certyfikatach dotyczących zarządzania } \\
\text { jakością } \\
\text { - informacja o wartościach niematerialnych w sprawozdaniu finansowym: } \\
\text { podział na nakłady na trwające prace rozwojowe, koszty zakończonych } \\
\text { prac rozwojowych, patenty i licencje oraz inne wartości niematerialne } \\
\text { i prawne } \\
\text { - informacja o przeprowadzanych testach na utratę wartości w odniesieniu } \\
\text { do prac rozwojowych i konieczności dokonania odpisów aktualizujących } \\
\text { (2018) w związku z przyjęciem bardziej ostrożnych założeń do testów } \\
\text { - zagadnienia dotyczące środowiska naturalnego } \\
\text { - opis systemu kontroli wewnętrznej i zarządzania ryzykiem (w odnie- } \\
\text { sieniu do sporządzania sprawozdań finansowych) } \\
\text { - procedury dotyczące podziału obowiązków przy sprawozdawczości } \\
\text { finansowej, informacja o eksploatowanym systemie finansowo- } \\
\text {-księgowym i zakładowym planie kont }\end{array}$ \\
\hline
\end{tabular}


cd. tabeli 3

\begin{tabular}{|c|c|}
\hline Spółka & Ujawniane informacje \\
\hline Mabion SA & $\begin{array}{l}\text { - certyfikaty potwierdzające zgodność produkcji i badań laboratoryjnych } \\
\text { z dobrymi praktykami } \\
\text { - opis czynności wykonywanych w procesie monitoringu, rewizji, i aktu- } \\
\text { alizacji potencjalnych rodzajów ryzyka } \\
\text { - zagadnienia dotyczące środowiska naturalnego } \\
\text { - informacja o funkcjonujących w spółce procedurach i rodzajach polityki } \\
\text { (polityka równych szans, wartości etyczne i sposób przeprowadzania } \\
\text { procesu rekrutacyjnego) } \\
\text { - informacja o perspektywach rozwoju i strategii i stanie jej realizacji } \\
\text { (2017) oraz informacja o decyzji zarządu spółki o aktualizacji strategii } \\
\text { (2018) }\end{array}$ \\
\hline Master Pharm SA & $\begin{array}{l}\text { - informacja o pozytywnym wyniku audytu certyfikacyjnego - certyfikat } \\
\text { ISO 22000:2005 (2018) } \\
\text { - opis cech systemów kontroli wewnętrznej i zarządzania ryzykiem }\end{array}$ \\
\hline Pharmena SA & $\begin{array}{l}\text { - informacja o badaniu skuteczności wytwarzanych produktów przez } \\
\text { zewnętrzne ośrodki badawcze } \\
\text { - informacja o procesie komercjalizacji leku } \\
\text { - informacja w sprawozdaniu finansowym o kwocie zakończonych prac } \\
\text { badawczo-rozwojowych i sposobie dokonywania odpisów oraz o kosz- } \\
\text { tach prac badawczo-rozwojowych (które nie zostały zakwalifikowane } \\
\text { do wartości niematerialnych i prawnych) } \\
\text { - informacja o podpisaniu umowy dotyczącej udzielenia licencji spółce } \\
\text { zależnej (2018) }\end{array}$ \\
\hline
\end{tabular}

Źródło: opracowanie własne na podstawie sprawozdań finansowych i sprawozdań z działalności badanych spółek.

Informację o procedurach obowiązujących w spółce zawarły: Bioton (kontrola jakości, bezpieczeństwo informacji, przeciwdziałanie korupcji, prawa człowieka, bezpieczeństwo i zgodność, etyka), PZ Cormay (kontrola wewnętrzna i zarządzanie ryzykiem w odniesieniu do sporządzania sprawozdania finansowego, podział obowiązków w sprawozdawczości finansowej), Mabion (polityka równych szans, etyka, rekrutacja, a także procedura monitoringu, rewizji i aktualizacji potencjalnych rodzajów ryzyka) oraz Master Pharm (kontrola wewnętrzna i zarządzanie ryzykiem).

Pozytywnie należy ocenić ujawnienie zagadnień dotyczących ochrony środowiska i wpływu prowadzonej działalności na środowisko naturalne. Takie informacje ujawniły: Bioton, Celon Pharma, PZ Cormay i Mabion. Ponadto, Biomed-Lublin, Celon Pharma i Mabion raportowały o obowiązujących w tych spółkach strategiach oraz wprowadzanych w tym zakresie zmianach, co również ma istotne znaczenie dla obecnych i potencjalnych interesariuszy. 
Informacja dotycząca kapitału relacyjnego, jaki posiadają badane spółki, ujawniana była w sprawozdaniach z działalności tych spółek. Szczegółowość raportowania w latach 2017 i 2018 dla poszczególnych spółek nie uległa istotnym zmianom. Wszystkie badane spółki z podobną szczegółowością ujawniały informacje o rynkach zbytu, źródłach zaopatrzenia oraz o sytuacji rynkowej w branży, w której działają w okresach sprawozdawczych, których dotyczyły badane sprawozdania. Wszystkie badane podmioty ujawniały również informacje dotyczące sprzedaży produktów, wskazując np. na możliwości wejścia na nowe rynki, podpisane, planowane do podpisania lub rozwiązane umowy dystrybucyjne czy modele sprzedaży. Informacje o otrzymanym bądź spodziewanym dofinansowaniu prac badawczo-rozwojowych z funduszy Unii Europejskiej znalazły się w sprawozdaniach z działalności wszystkich spółek, z wyjątkiem spółki Pharmena. Pozostałe informacje raportowane przez spółki zostały przedstawione w tabeli 4.

Tabela 4. Informacje dotyczące kapitału relacyjnego ujawniane w sprawozdaniach finansowych i sprawozdaniach z działalności przez badane spółki w latach 2017 i 2018

\begin{tabular}{|c|c|}
\hline Spółka & Ujawniane informacje \\
\hline Wszystkie spółki & $\begin{array}{l}\text { - informacja o rynkach zbytu, źródłach zaopatrzenia, sytuacji rynkowej } \\
\text { w branży, w której działają spółki } \\
\text { - informacje dotyczące sprzedaży produktów (np. wskazywanie } \\
\text { na możliwości wejścia na nowe rynki, umowy dystrybucyjne, infor- } \\
\text { macja o modelach sprzedaży) } \\
\text { - informacja o dofinansowaniu prac badawczo-rozwojowych } \\
\text { z funduszy Unii Europejskiej (z wyjątkiem spółki Pharmena) }\end{array}$ \\
\hline $\begin{array}{l}\text { Biomed-Lublin } \\
\text { Wytwórnia Surowic } \\
\text { i Szczepionek SA }\end{array}$ & $\begin{array}{l}\text { - informacja o korzystnej lokalizacji (Lublin - ośrodek akademicki, } \\
\text { możliwość pozyskania wykwalifikowanej kadry) } \\
\text { - wskazanie na współpracę z ośrodkami badawczymi w kraju i za granicą } \\
\text { - wytwarzanie w oparciu o technologię }\end{array}$ \\
\hline Bioton SA & $\begin{array}{l}\text { - informacja o relacjach ze społecznościami lokalnymi, komunikacja } \\
\text { społeczna } \\
\text { - organizacja kampanii informacyjnych na temat cukrzycy, zdrowego } \\
\text { stylu życia, działania na rzecz pacjentów (darowizny leków, wolontariat } \\
\text { pracowniczy) } \\
\text { - informacja o powiązaniach organizacyjnych i kapitałowych } \\
\text { - informacja o podpisaniu umowy ramowej dotyczacej globalnej dystry- } \\
\text { bucji i marketingu (2018) }\end{array}$ \\
\hline Celon Pharma SA & $\begin{array}{l}\text { - informacja o strategiach partneringowych w działaniach innowacyjnych } \\
\text { dotyczących badań nad nowymi lekami (2017) } \\
\text { - informacja o umowach dotyczących rozwoju przemysłowego i wytwa- } \\
\text { rzania do badań klinicznych }\end{array}$ \\
\hline PZ Cormay SA & $\begin{array}{l}\text { - informacja o współpracy z jednostkami leczniczymi (2017) } \\
\text { - udział w projekcie dofinansowanym przez PARP - targi, konferencje } \\
\text { branżowe (2017) }\end{array}$ \\
\hline
\end{tabular}


cd. tabeli 4

\begin{tabular}{|c|c|}
\hline Spółka & Ujawniane informacje \\
\hline Mabion SA & $\begin{array}{l}\text { - informacja o współpracy z Wydziałem Biologii i Ochrony Środowiska } \\
\text { Uniwersytetu Łódzkiego } \\
\text { - informacja o zdobytych nagrodach i wyróżnieniach (2017) } \\
\text { oraz o udziale w konferencjach } \\
\text { - informacja o udziale pacjentów w badaniach (2017) } \\
\text { - informacja o zamiarze podjęcia projektów we współpracy z partnerami } \\
\text { (2018) } \\
\text { - informacja o komunikacji z inwestorami (spotkania edukacyjne } \\
\text { dla przedstawicieli rynku kapitałowego, serwis internetowy z materia- } \\
\text { łami dla inwestorów) } \\
\text { - informacja o uzyskaniu zezwolenia na działalność na terenie Łódzkiej } \\
\text { SSE (2017) }\end{array}$ \\
\hline Master Pharm SA & $\begin{array}{l}\text { - informacja o działalności sponsoringowej i charytatywnej } \\
\text { - informacja o nagrodach uzyskanych przez produkty spółki (2017) }\end{array}$ \\
\hline Pharmena SA & $\begin{array}{l}\text { - informacja o współpracy z głównymi ośrodkami badawczo-rozwojo- } \\
\text { wymi w USA i Kanadzie poprzez spółkę zależną } \\
\text { - informacja o prowadzonych w ramach działań marketingowych spotka- } \\
\text { niach ze środowiskami medycznymi i farmaceutycznymi } \\
\text { - informacja o posiadaniu własnej grupy przedstawicieli w środowiskach } \\
\text { medycznych i farmaceutycznych (2017) } \\
\text { - informacja o zdobytych nagrodach i wyróżnieniach (2017) }\end{array}$ \\
\hline
\end{tabular}

Źródło: opracowanie własne na podstawie sprawozdań finansowych i sprawozdań z działalności badanych spółek.

Na współpracę z krajowymi bądź zagranicznymi ośrodkami badawczo-rozwojowymi oraz leczniczymi wskazały: Biomed-Lublin, PZ Cormay, Mabion i Pharmena. Ponadto spółka Mabion ujawniła w 2017 r. informację o udziale pacjentów w prowadzonych badaniach. Informacje dotyczące działań marketingowych i komunikacji z inwestorami ujawniły: Bioton, Celon Pahrma, Mabion i Pharmena. Informacje o otrzymanych przez spółki lub wytwarzane przez nie produkty nagrodach i wyróżnieniach zostały ujawnione przez Mabion, Master Pharm i Pharmena. Z kolei Bioton i Master Pharm wskazywały w swoich sprawozdaniach na relacje ze społecznościami lokalnymi, działalność na rzecz pacjentów, działalność charytatywną i sponsoringową.

Na podstawie powyższych zestawień należy stwierdzić, że sprawozdania za lata 2017 i 2018 wszystkich badanych spółek spełniały wymagania ustawowe dotyczące sprawozdawczości niefinansowej, o której jest mowa w art. 49 uor, a dodatkowo spółka Bioton raportowała informacje w sposób rozszerzony zgodnie $\mathrm{z}$ wymaganiami art. 49b uor, w związku z przekraczaniem wymienionych w nim wielkości. 
Należy jednak zwrócić uwagę, że spełnianie wymagań ustawowych nie zawsze będzie stanowiło o wystarczającej szczegółowości ujawnianych informacji w kontekście kapitału intelektualnego. Na podstawie przeprowadzonych badań sprawozdań z działalności i finansowych za lata 2017 i 2018 można stwierdzić, że szczegółowość ujawnianych informacji o kapitałach: ludzkim, strukturalnym i relacyjnym w badanych spółkach różni się. Może to być spowodowane, zdaniem autorów, przede wszystkim brakiem ustawowych, ale również nieformalnych wymagań dotyczących sposobu i szczegółowości raportowania kapitału intelektualnego, co wielu badaczy wskazuje jako jedno z głównych wyzwań współczesnej rachunkowości.

\section{Podsumowanie}

Wzrost znaczenia kapitału intelektualnego w dobie gospodarki opartej na wiedzy stwarza konieczność wypracowania standardów związanych z ujawnianiem informacji dotyczących kapitału intelektualnego. $Z$ przeprowadzonych badań wynika, że szczegółowość ta jest zróżnicowana, a elementy wspólne, czyli ujawniane informacje wynikające $\mathrm{z}$ obowiązków ustawowych pojawiające się we wszystkich badanych sprawozdaniach finansowych i sprawozdaniach z działalności lub większości z nich, mogą być w przypadku konieczności porównania znaczenia kapitału intelektualnego między badanymi spółkami niewystarczające dla uzyskiwanej przez nie przewagi konkurencyjnej, pozycji rynkowej czy osiąganych wyników finansowych.

Na podstawie przeprowadzonych badań należy stwierdzić, że poddane analizie spółki nie sporządzają odrębnego sprawozdania dotyczącego kapitału intelektualnego ani sprawozdania zintegrowanego, którego istotną część stanowi ujawnienie informacji o kapitale intelektualnym. Badane spółki ujawniają podstawowe informacje dotyczące kapitału ludzkiego, strukturalnego i relacyjnego, których znaczna część prezentowana jest $\mathrm{w}$ sprawozdaniach z działalności.

Należy również zaznaczyć, że badania zostały przeprowadzone na ograniczonej próbie, dlatego możliwość wyciągania wniosków jest istotnie ograniczona. Badania te mogą stanowić jedynie wstęp do szerszych badań (nie tylko w kontekście rynku polskiego) nad szczegółowością ujawnianych informacji o kapitale intelektualnym w sprawozdawczości finansowej i niefinansowej w spółkach branży lekowej, a w dalszej kolejności nad znaczeniem kapitału intelektualnego dla kondycji finansowej i pozycji w branży. 


\section{Literatura}

Chojnacka E., Bering A. (2018), Struktura ramowa raportu zintegrowanego - wytyczne a praktyka wybranych przedsiębiorstw, „Studia i Prace Kolegium Zarządzania i Finansów", nr 160.

Duff A. (2018), Intellectual Capital Disclosure: Evidence from UK Accounting Firms, „Journal of Intellectual Capital”, vol. 19, nr 4, https://doi.org/10.1108/JIC-06-2017-0079.

Dumay J. (2016), A Critical Reflection on the Future of Intellectual Capital: from Reporting to Disclosure, ,Journal of Intellectual Capital”, vol. 17, nr 1, https://doi.org/10.1108/JIC08-2015-0072.

Dyrektywa Parlamentu Europejskiego i Rady 2014/95/UE z dnia 22 października 2014 r. zmieniająca dyrektywę 2013/34/UE w odniesieniu do ujawniania informacji niefinansowych i informacji dotyczących różnorodności przez niektóre duże jednostki oraz grupy, Dz. Urz. UE L 330 z 15.11.2014 r.

Edvinsson L., Malone M.S. (2001), Kapitat intelektualny, Wydawnictwo Naukowe PWN, Warszawa.

Inkinen H., Kianto A., Vanhala M., Ritala P. (2017), Structure of Intellectual Capital an International Comparison, „Accounting, Auditing \& Accountability Journal”, vol. 30, nr 5, https://doi.org/10.1108/AAAJ-11-2015-2291.

The International Integrated Reporting Framework (2013), The International Integrated Reporting Council, https://integratedreporting.org/wp-content/uploads/2015/03/13-1208-THE-INTERNATIONAL-IR-FRAMEWORK-2-1.pdf (data dostępu: 8.03.2020).

Kwiecińska K. (2018), Sposoby ujawniania informacji o kapitale intelektualnym w praktyce spółek notowanych na GPW w Warszawie, ,Prace Naukowe Uniwersytetu Ekonomicznego we Wrocławiu", nr 503, https://doi:10.15611/pn.2018.503.27.

Michalczuk G., Mikulska T. (2014), Sprawozdanie zintegrowane jako finalny produkt rachunkowości społecznej, ,Zeszyty Naukowe Uniwersytetu Szczecińskiego nr 827. Finanse, Rynki Finansowe, Ubezpieczenia", nr 69.

Międzynarodowy Standard Rachunkowości 1 Prezentacja sprawozdań finansowych, Dz. Urz. UE L 339/3 z 18.12.2008 r.

Mouritsen J. (2009), Classification, Measurement and the Ontology of Intellectual Capital Entities, ,Journal of Human Resource Costing \& Accounting”, vol. 13, nr 2, https://doi. org/10.1108/14013380910968665.

Niemczyk L. (2015), Kapitał intelektualnych w księgach rachunkowych oraz sprawozdawczości przedsiębiorstwa, Wydawnictwo Uniwersytetu Rzeszowskiego, Rzeszów.

Piech K. (2004), Gospodarka oparta na wiedzy i jej rozwój w Polsce, ,E-mentor” nr 4(6), http://www.e-mentor.edu.pl/artykul/index/numer/6/id/75 (data dostępu: 16.11.2019).

Rewizja dyrektywy w sprawie ujawniania informacji niefinansowych-konsultacje publiczne $K E$ (2020), https://www.gov.pl/web/finanse/rewizja-dyrektywy-w-sprawie-ujawnianiainformacji-niefinansowych--konsultacje-publiczne-ke (data dostępu: 30.06.2020).

Skoczylas W., Dziadul W. (2018), Diagnoza zakresu ujawniania informacji niefinansowych przez przedsiębiorstwa polskie, „Studia i Prace Kolegium Zarządzania i Finansów", nr 164.

Skrzypek E. (2017), Raportowanie kapitału intelektualnego organizacji, „Prace Naukowe Uniwersytetu Ekonomicznego we Wrocławiu", nr 481, https://doi:10.15611/pn.2017.481.07.

Sokołowski J. (2018), Kapitał intelektualny a innowacyjność przedsiębiorstwa, „Zarządzanie innowacyjne w gospodarce i biznesie" nr 2(27), https://doi.org/10.25312/ 2391-5129.27/2018_02js. 
Szczepankiewicz E.I. (2012), The Use of InCaS Model for Estimating the Value of Human Capital in Future-oriented Organizations, ,Human Resources Management \& Ergonomics", vol. VI, nr 1.

Szczepankiewicz E.I. (2013), Concept of Using the InCaS Model to Identification, Measuring and Presenting Relational Capital of a Network Enterprises, ,Management", vol. 17, nr 1, https://doi.org/10.2478/manment-2013-0010.

Ujwary-Gil A. (2010), Kapitał intelektualny-problem interpretacji kluczowych terminów, „Organizacja i Kierowanie”, nr 2(140).

Ustawa z dnia 29 września 1994 r. o rachunkowości, Dz.U. nr 121, poz. 591, tekst jednolity: Dz.U. 2019, poz. 351.

Wisła R., Sierotowicz T. (2018), Innowacyjność w branżach farmaceutycznej $i$ wyrobów medycznych w Polsce, ,Economic Research Working Paper” nr 45, https://ruj.uj.edu. $\mathrm{pl} / \mathrm{xmlui} /$ bitstream/handle/item/63361/wisla_sierotowicz_innowacyjnosc_w_branzach_farmaceutycznej_i_wyrobow_medycznych_w_polsce_2018.pdf?sequence= 4\&isAllowed=y (data dostępu: 6.04.2020).

\section{Information on Intellectual Capital in the Financial Statements and Annual Activity Reports of Pharmaceutical Companies}

(Abstract)

Objective: The aim of the article is to examine the detailed disclosure of information on intellectual capital in the financial statements and annual activity reports in 2017 and 2018 of pharmaceutical companies registered in Poland and listed on the Warsaw Stock Exchange. Research Design \& Methods: The study was preceded by a review of the literature on the subject, including scientific articles, monographs, industry reports and legal acts. The study is based on the examination of financial statements and annual activity reports of the analysed companies.

Findings: The companies examined do not prepare separate reports on intellectual capital, but include the information in their activity reports and financial statements. There is no standardised way for that information to be included.

Implications/Recommendations: The differentiation characterising the information disclosed on intellectual capital confirms the need to standardise information on intellectual capital disclosed in activity reports and financial statements.

Contribution: This study can be treated as an introduction to the wider research on the disclosure of information about intellectual capital in the pharmaceutical industry, as well as on the importance of intellectual capital for the companies' financial condition.

Keywords: intellectual capital, annual activity report, financial statement, pharmaceutical industry. 